\title{
Trophoblastic interferon-gamma: current knowledge and possible role(s) in early pig pregnancy
}

\author{
Avrelija CEnCIČa*, Claude LA BonNARDIÈRE ${ }^{\mathrm{b}}$ \\ ${ }^{a}$ University of Maribor, Faculty of Agriculture, Vrbanska c.30, 2000 Maribor, Slovenia \\ b INRA, Unité de Virologie et Immunologie Moléculaires, Domaine de Vilvert, \\ 78352 Jouy-en-Josas Cedex, France
}

(Received 31 August 2001; accepted 29 November 2001)

\begin{abstract}
In the pig as in ruminant species, the implantation of the elongated conceptus - the embryo with its associated membranes - onto the maternal uterus is accompanied by an intense secretion of interferon (IFN), which culminates at day 15 of development. It has been shown that in fact the pig trophectoderm - the polarized epithelium which lines the conceptus - simultaneously secretes two types of interferons: IFN-gamma (IFN- $\gamma$ ), which is the more abundant species, is produced in very substantial amounts. Another IFN is also secreted, which happens to be a novel type I IFN, now named IFN- $\delta$. It was previously shown that the uterus is the most probable target of the pig trophoblastic IFNs, since no autocrine effect was found on the trophoblast. It has also been shown that, unlike for the ruminant species, the pig trophoblastic IFNs do not play an apparent role in the so-called maternal recognition of pregnancy. We have focused this review on IFN- $\gamma$, because first, it is the major species secreted and secondly, IFN- $\gamma$ has various regulatory effects on different tissues, including lymphoid cells. We particularly address the question of the possible role of trophoblastic IFN- $\gamma$ in early pregnancy, in the light of the known biological functions of human and mouse IFN- $\gamma$.
\end{abstract}

interferon-gamma / embryo / trophoblast / pig / implantation

Résumé - Interféron-gamma trophoblastique : état actuel des connaissances et rôle(s) possible(s) en début de gestation chez le porc. Chez le porc, comme chez les ruminants, l'implantation du conceptus (l'embryon et ses membranes annexes) dans l'utérus maternel s'accompagne d'une intense sécrétion d'interféron (IFN), laquelle culmine au $15^{\mathrm{e}}$ jour du développement. On a montré que le trophectoderme - l'épithélium polarisé qui borde le conceptus - sécrète simultanément deux types d'IFN : l'IFN-gamma, qui est le plus abondant, est produit en très grande quantité. L'autre interféron, apparenté aux IFN de type I, s'avère être une nouvelle espèce, nommée IFN- $\delta$. Des résultats antérieurs ont montré que l'utérus est la cible la plus probable des interférons trophoblastiques, puisqu'aucun effet autocrine

\footnotetext{
* Correspondence and reprints

Tel.: (386) 22505 800; fax: (386) 222960 71; e-mail: avrelija.cencic@uni-mb.si
} 
n'a été mis en évidence sur le trophoblaste. On sait par ailleurs que, contrairement aux ruminants, les IFN trophoblastiques, chez le porc, ne jouent apparemment aucun rôle dans le phénomène appelé reconnaissance maternelle de la gestation. L'accent est mis dans cette revue sur l'IFN-gamma, qui constitue l'essentiel de l'IFN sécrété, et auquel on attribue de nombreux effets régulateurs sur différents tissus, y compris sur les cellules du système immunitaire. Nous posons en particulier la question du rôle possible de l'IFN- $\gamma$ trophoblastique en début de gestation, à la lumière des fonctions biologiques connues de l'IFN- $\gamma$ chez l'homme et la souris.

\section{interféron-gamma / embryon / trophoblaste / porc / implantation}

\section{Table of contents}

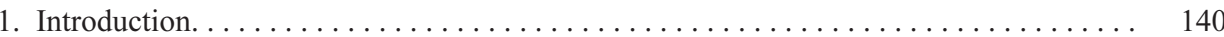

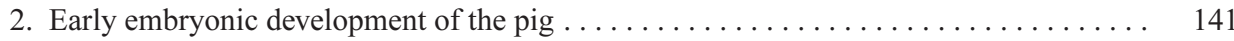

2.1. Morphology and functional characteristics of the elongating trophoblast....... 141

2.2. Embryonic-maternal interaction during the implantation period . . . . . . . . . . . 141

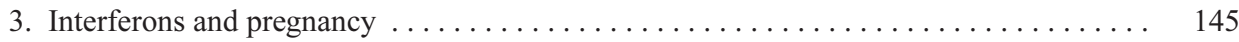

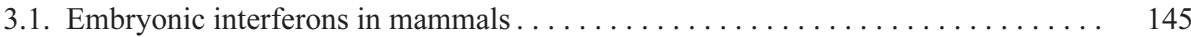

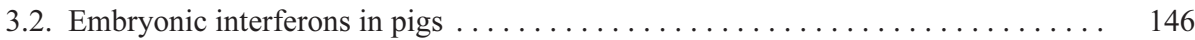

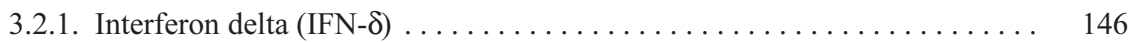

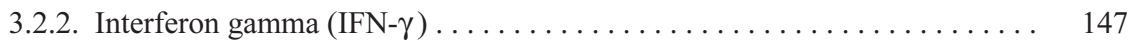



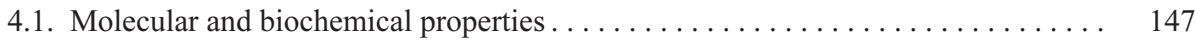

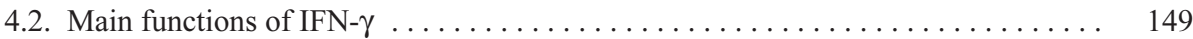

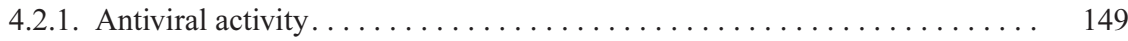

4.2.2. Antimicrobial activity. . . . . . . . . . . . . . . . . . . . . 149

4.2.3. Immunomodulation . . . . . . . . . . . . . . . . . . . . . . . 149

4.2.4. Interactions with cellular adhesion molecules . . . . . . . . . . . . 150

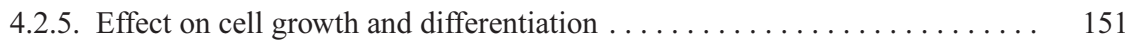

5. Possible role(s) of porcine embryonic interferon- $\gamma \ldots \ldots \ldots \ldots \ldots \ldots \ldots \ldots \ldots \ldots \ldots \ldots$

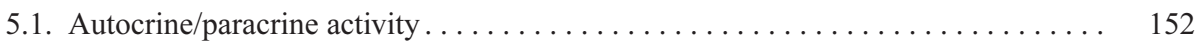

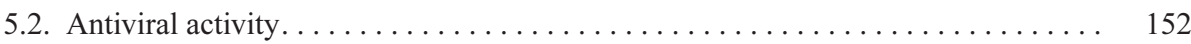

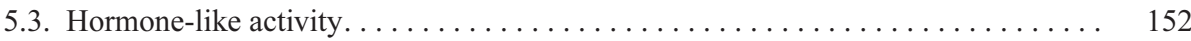

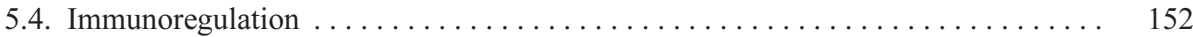

5.5. Possible role in conceptus implantation . . . . . . . . . . . . . . . . . 153

6. Conclusion ... . . . . . . . . . . . . . . . . . . . . . . . . . . . . . . . . . . . 154

\section{INTRODUCTION}

As in all mammalian species, implantation of the blastocyst onto the maternal endometrium is one of the most important events in the establishment and maintenance of pregnancy in the pig. In spite of the known facts that several factors, like hormones, growth factors and cytokines regulate maternal recognition of pregnancy, it was unexpectedly found that just before implantation, the pig trophoblast secretes large amounts of interferon gamma (IFN- $\gamma$ ) and a novel interferon delta (IFN- $\delta$ ) $[45,48$, 
49]. Production of these embryonic interferons by the trophoblast, particularly IFN- $\gamma$, is a unique case, as is its source of secretion and the fact it being developmentally induced. To date, the function of these embryonic interferons still remains unknown. This paper contributes to the insight of the present knowledge of embryonic IFNs, and their possible role in early pregnancy in pigs.

\section{EARLY EMBRYONIC DEVELOPMENT OF THE PIG}

Whereas the pig is widely used as a model for studies in several fields of human biology due to many common anatomical and physiological features, its placentation differs entirely from that of primates [5].

The epitheliochorial placenta occurring in pigs consists of an apposition and attachment of foetal membranes to the maternal endometrium, after a prolonged preimplantation period. During the apposition stage, first true cellular contacts between the trophoblast and the uterine endometrium are established, accompanied by a reduction in the apical microvilli covering the trophoblastic cells. The fixation of the blastocyst onto the endometrium is ensured by interdigitation of uterine and trophoblastic microvilli [32]. Implantation of the blastocyst ends without trophoblast invasion into the maternal tissue, although it has been found that trophoblast does secrete a plasminogen activator $[58,69]$.

\subsection{Morphology and functional characteristics of the elongating trophoblast}

In the period which precedes the critical step of attachment (days 9-14 of pregnancy), the blastocyst undergoes pronounced expansion. By day 10 of pregnancy, the pig conceptus evolves from a spheric $(1-3 \mathrm{~mm})$ to an ovoid shape $(9-10 \mathrm{~mm})$, then to a tubular $(12-30 \mathrm{~mm})$ and finally to a thin filamentous form (up to $100 \mathrm{~mm}$ in length) prior to implantation [26, 28] (Fig. 1). This extreme trophoblastic elongation occurs through massive cellular remodelling of the trophectoderm and endoderm. In this process, actin-containing microfilaments undergo extensive intracellular reorganisation and rearrange the trophectoderm plasma membrane [28, 57]. Elongation along the uterine endometrium permits trophoblast adhesion throughout the uterine lumen and continuous adhesive attachment during pregnancy. Attachment of the blastocyst is completed at day 20 of gestation $[25,57,70]$. The trophoblast consists of a layer of polarised cells with tight intercellular junctional complexes, allowing selective permeability of various uterine substances. The polarised trophoblast is capable of a variety of functions, such as the distribution of enzymes and transport systems to specific domains of the plasma membrane. In addition, the trophoblast expresses membrane receptors, synthesises and secretes steroid hormones (oestrogens) and proteins (interferons and other cytokines) that participate in the metabolic, endocrinological and possibly immunological functions required for the establishment and maintenance of pregnancy [43].

\subsection{Embryonic-maternal interaction during the implantation period}

Implantation follows a prolonged preimplantation (prereceptive) period, characterised by migration, spacing and elongation of conceptuses. Transition to the receptive state is controlled by conceptus derived oestrogens [7]. Blastocyst invasion of the endometrial stroma and decidualisation (a significant modification of uterine stroma, implying proliferation and differentiation of stromal fibroblasts and glandular atrophy) does not occur in pigs. Although the preimplantation pig trophoblast secretes the plasminogen activator, a proteolytic enzyme 


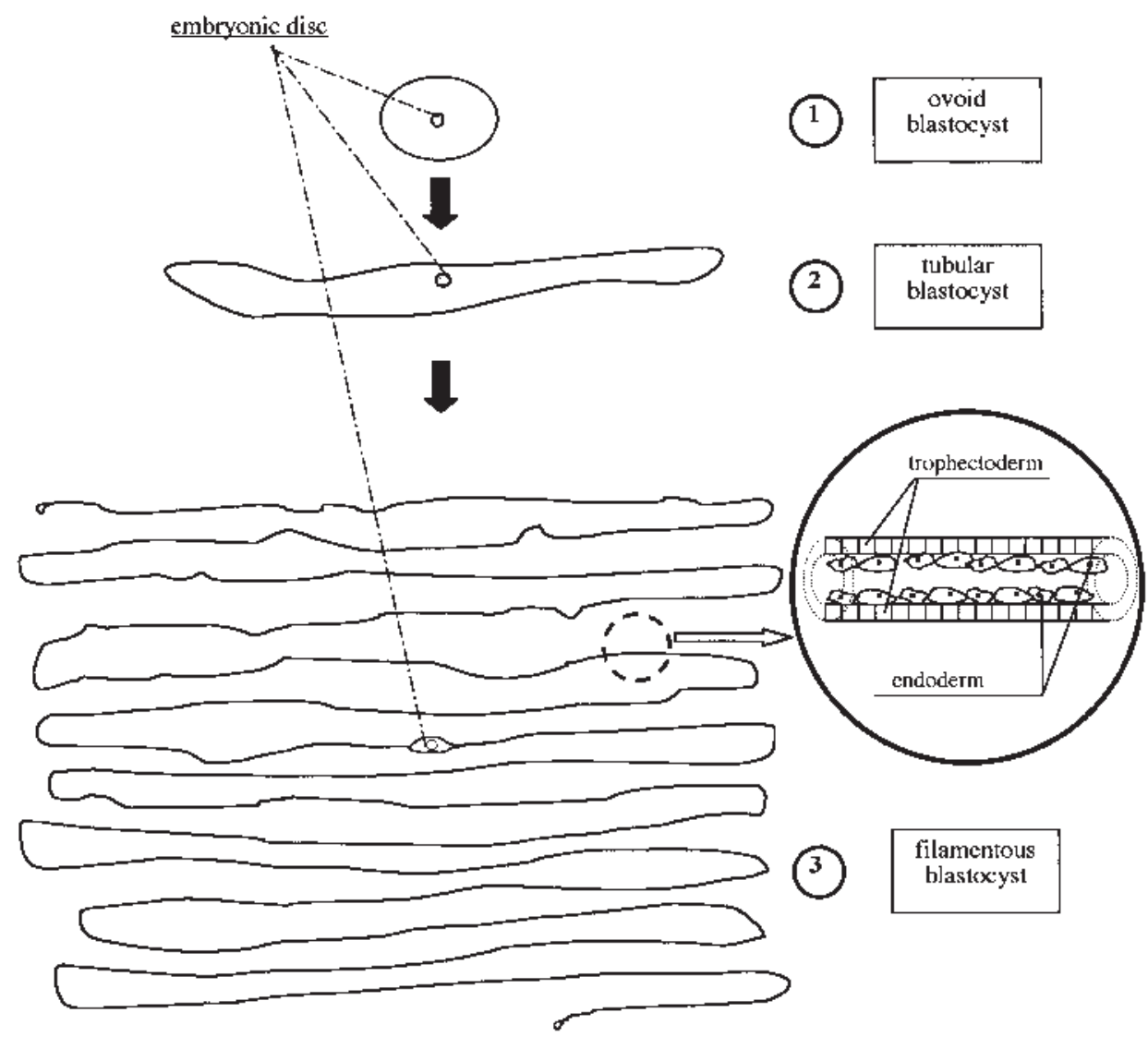

Figure 1. Morphology of early pig conceptus. By days $8-9$, the blastocyst is spherical to ovoid, with a diameter of 9-10 mm (stage 1). On days 9-10, the blastocyst becomes tubular, with a size between 12 and $30 \mathrm{~mm}$ (stage 2). Finally, the blastocyst undergoes a profound remodelling, which results, by days 11-12, in an elongated filamentous blastocyst (conceptus) with a length up to $100 \mathrm{~mm}$ (stage 3 ).

that is secreted by many invasive cell types, it is simultaneously blocked by the uterus secreted plasminogen activator inhibitor, induced by progesterone $[32,69]$. The trophoblast and its supporting layer of the extra-embryonic mesoderm is simply apposed to the uterine epithelium. The implantation process is complete with the formation of the placenta, which supports foetal development up to the end of pregnancy [7] (Fig. 2).
Fusion of embryonic and maternal membranes during implantation leads to biophysical alterations, favouring the ultimate fusion of the membranes. In the receptive phase, the negatively charged apical glycocalyx of the maternal luminal epithelium diminishes, leading to its reduction in thickness at the implantation site during initial attachment. According to the model of Laloraya, the increase in the bulk lipid fluidity and an increase in polarity of the 


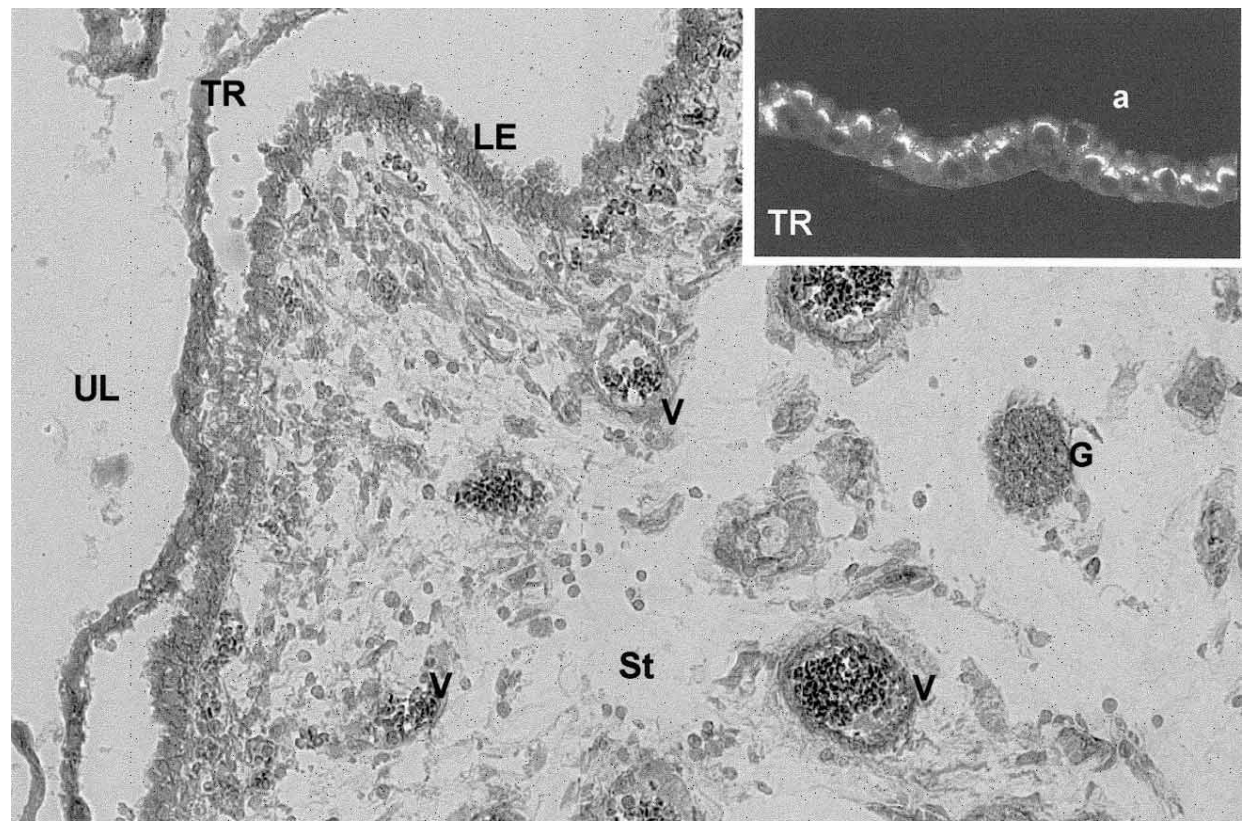

Figure 2. The pig uterine lumen: two facing epithelia. Frozen section of a pregnant Large White uterus at day 15 of pregnancy (magnif. $200 \times$ ). In the uterine lumen (UL), the elongated trophoblast (TR) is facing the uterine luminal epithelium (LE), and at some places is apposed to it. Note in the uterine stroma (St) the presence of blood vessels (V) and glands $(\mathrm{G})$. An enlarged view of the embryonic trophectoderm at the same stage is shown in the top right box (magnif. $400 \times$ ). IFN- $\gamma$, as revealed by specific anti-IFN- $\gamma$ immunofluorescence, is synthesised towards the apex (a) of the trophectoderm.

phospholipid bilayer has been suggested to be responsible for the act of implantation [47]. Simultaneously, lectin-binding characteristics of the pig blastocyst surface change just before attachment. The progesterone-induced structural changes result in the reduction of epithelial polarity, loss of apical microvilli, alteration of tight junction organisation and close apposition of the conceptus and apical uterine epithelium [16]. Adhesion events that occur during implantation involve different adhesion molecules among which integrins are dominant species. Integrins belong to a family of glycoconjugates which are expressed on the uterine luminal epithelium and are directly involved in the process of implantation. Integrin subunits $\alpha 4, \alpha 5, \alpha v, \beta 1$ and $\beta 2$ are expressed on the trophoblast and uterine epithelium that are in contact at the implantation site. Fibronectin and vitronectin constituents of the extracellular matrix, are also present on the pig conceptus, whereas vitronectin is present on the uterine epithelium at the implantation phase [25].

The conditions that control the developmental expression of adhesion receptors and ligands in the uterus are regulated precisely through the action of ovarian steroids, growth factors and cytokines. Potential cytokines that could initiate the implantation cascade include the following: the transforming growth factor $\beta 1$ (TGF- $\beta 1$ ), granulocyte-macrophage colonystimulating factor (GM-CSF), interleukin $1 \beta$ (IL-1 $\beta$ ) and interferon $\gamma$ (IFN- $\gamma$ ) [7]. The uterine endometrium secretes another 
Table I. Main characteristics of the interferons (Data are for porcine IFN, unless otherwise stated)

\begin{tabular}{|c|c|c|c|c|c|c|c|c|c|c|c|}
\hline \multirow[t]{2}{*}{ Type } & \multirow{2}{*}{$\begin{array}{l}\text { IFN } \\
\text { species }\end{array}$} & \multirow{2}{*}{$\begin{array}{l}\text { Gene } \\
\text { structure } \\
\text { (chromos.) }\end{array}$} & \multirow{2}{*}{$\begin{array}{l}\text { Major } \\
\text { inducers }\end{array}$} & \multirow{2}{*}{$\begin{array}{l}\text { Cellular } \\
\text { source }\end{array}$} & \multirow[t]{2}{*}{ Structure } & \multirow{2}{*}{$\begin{array}{l}\text { Receptor } \\
\text { type }\end{array}$} & \multicolumn{5}{|c|}{ Physico-chemical characteristics } \\
\hline & & & & & & & $\begin{array}{l}\mathrm{M}_{\mathrm{r}}- \\
\text { (monomers) }\end{array}$ & $\begin{array}{l}\mathrm{pH} 2 \\
\text { stability }\end{array}$ & $\begin{array}{l}\text { Thermo- } \\
\text { stability }\end{array}$ & $\begin{array}{l}\text { N-linked } \\
\text { glycosylation }\end{array}$ & $\begin{array}{l}\text { pI } \\
\text { (theoret) }\end{array}$ \\
\hline \multirow[t]{5}{*}{ type I } & alpha $(\alpha)$ & $\begin{array}{l}\text { multigene } \\
\text { family of at } \\
\text { least } 12 \text { loci } \\
\text { (Chr 1- short } \\
\text { arm) }\end{array}$ & $\begin{array}{l}\text { viruses, } \\
\text { infected } \\
\text { cells, } \\
\text { bacteria }\end{array}$ & $\begin{array}{l}\text { leucocytes, } \\
\text { macrophages }\end{array}$ & $\begin{array}{l}\text { IFN- } \alpha 1: \\
166 \text { aa } \\
\text { IFN- } \alpha 2: \\
158 \text { aa } \\
\text { a single } \\
\text { polypeptide }\end{array}$ & $\begin{array}{ll}1 \\
1 \\
2\end{array}$ & $\begin{array}{l}\text { a single, } \\
\text { non } \\
\text { glycosylated } \\
\text { polypeptide } \\
25200- \\
28700\end{array}$ & + & + & - & 7.21 \\
\hline & beta $(\beta)$ & $\begin{array}{l}\text { a single } \\
\text { intronless } \\
\text { gene } \\
(\mathrm{Chr} 11) \\
\end{array}$ & $\begin{array}{l}\text { viruses, } \\
\text { dsRNA }\end{array}$ & fibroblasts & $\begin{array}{l}165 \text { aa } \\
\text { glycosylated } \\
\text { dimer }\end{array}$ & I & $\begin{array}{l}\text { data } \\
\text { not found }\end{array}$ & + & - & + & \\
\hline & omega $(\omega)$ & $\begin{array}{l}\text { multigene } \\
\text { family of } 6 \text { or } \\
7 \text { loci }\end{array}$ & $\begin{array}{l}\text { viruses, } \\
\text { others? }\end{array}$ & $\begin{array}{l}\text { leukocytes, } \\
\text { others? }\end{array}$ & $\begin{array}{l}\text { IFN- } \omega 3 \text { : } \\
167 \text { aa, } \\
\text { IFN- } \omega 4 \text { : } \\
156 \text { aa, } \\
\text { IFN- } \omega 5: \\
167 \text { aa } \\
\text { a single } \\
\text { polypeptide }\end{array}$ & I & $\begin{array}{l}\text { data } \\
\text { not found }\end{array}$ & $\begin{array}{l}\text { data } \\
\text { not found }\end{array}$ & $\begin{array}{l}\text { data } \\
\text { not found }\end{array}$ & $\begin{array}{l}\text { data } \\
\text { not found }\end{array}$ & $\begin{array}{l}\text { data } \\
\text { not found }\end{array}$ \\
\hline & $\begin{array}{l}\text { tau }(\tau) \\
\text { (ruminants) }\end{array}$ & $\begin{array}{l}\text { Chr } 2 \text { sheep, } \\
\text { Chr } 8 \text { cattle }\end{array}$ & $\begin{array}{l}\text { embry- } \\
\text { onic } \\
\text { (develop. } \\
\text { induced) }\end{array}$ & trophoblast & 172 aа & I & / & l & / & / & $\begin{array}{l}\text { data } \\
\text { not found }\end{array}$ \\
\hline & delta $(\delta)$ & $\begin{array}{l}\text { a single } \\
\text { intronless gene }\end{array}$ & $\begin{array}{l}\text { embry- } \\
\text { onic } \\
\text { (develop. } \\
\text { induced) }\end{array}$ & trophoblast & $\begin{array}{l}149 \text { aa } \\
\text { a single } \\
\text { polypeptide }\end{array}$ & I & $\begin{array}{l}1 \text { glycoform } \\
19000\end{array}$ & + & $\begin{array}{l}-/+(\text { SDS } \\
\text { thermosta- } \\
\text { bilization) }\end{array}$ & one-Asn 79 & 9.9 \\
\hline \multirow[t]{2}{*}{ type II } & $\underset{\text { "adult" }}{\text { gamma }}(\gamma)$ & $\begin{array}{l}\text { a single gene } \\
\text { with } 3 \text { introns } \\
\text { (Chr 5, with } \\
\text { micro- } \\
\text { satellites) }\end{array}$ & $\begin{array}{l}\text { antigens, } \\
\text { mitogens }\end{array}$ & $\begin{array}{l}\text { T lymphocytes, } \\
\text { NK cells }\end{array}$ & $\begin{array}{l}143 \text { aa } \\
\text { noncovalent } \\
\text { homodimer }\end{array}$ & II & $\begin{array}{l}1 \text { glycoform } \\
28000- \\
30000\end{array}$ & - & - & $\begin{array}{l}\text { two- } \\
\text { Asn 24/ } \\
\text { Asn } 83\end{array}$ & 9.87 \\
\hline & $\underset{\text { "embryonic", }}{\text { gamma }(\gamma)}$ & $\begin{array}{l}\text { as leucocytic } \\
\text { IFN- } \gamma\end{array}$ & $\begin{array}{l}\text { Embry- } \\
\text { onic } \\
\text { develop. } \\
\text { induced }\end{array}$ & trophoblast & $?$ & II & $\begin{array}{l}4 \text { glycoforms } \\
18500- \\
25000\end{array}$ & $-/+$ & $?$ & $\begin{array}{l}\text { probably as } \\
\text { leucocytic } \\
\text { IFN- } \gamma\end{array}$ & $?$ \\
\hline
\end{tabular}


pleiotropic cytokine: a leukaemia inhibitory factor (LIF) just before the onset of implantation. It has been clearly shown in mice that maternal LIF expression is essential for blastocyst implantation [68].

The group of F.W. Bazer demonstrated that initial attachment of the conceptus to the uterine epithelium is accompanied by the downregulation of the anti-adhesive mucin, Muc-1, which may inhibit the interaction of the embryo with adhesion molecules on the interface of the blastocyst and uterine epithelium in the preimplantation phase [6]. Transduction of signals from the triggering molecules involves calcium fluxes, protein phosphorylation and/or cytoskeletal alterations [25]. In the Geisert model, the final adhesion event is mediated by the high affinity integrin-ligand interactions of fibronectin and vitronectin family of receptors $[7,25]$.

\section{INTERFERONS AND PREGNANCY}

Interferons (IFNs), discovered in 1957 by Isaacs and Lindenmann, represent a group of proteins with molecular weights up to 100000 and were initially related by their ability to protect cells from viral infections.

Today, IFNs are defined as proteins synthesised by vertebrate cells after exposure to a variety of stimuli and able to exert a broad spectrum of biological activities [39]. Their action is mainly local (autocrine or paracrine). If they are secreted into the blood, they can act at a distance.

Based on the antigenic, structural, biochemical and biological criteria, IFNs have been divided into two main types. Type I IFNs $(\alpha, \beta, \tau, \delta, \omega)$, include sequence-related, intronless IFN gene families. The IFN proteins bind to the same "Type I" IFN receptor on susceptible cells. Type II IFNs include a unique member - IFN- $\gamma$, that has a multipotential role in the immune response [39]. The main properties of IFNs are summarised in Table I.

\subsection{Embryonic interferons in mammals}

In the last decade, it has been found that in several mammalian species IFNs are secreted by the embryonic trophoblast in early pregnancy.

Interferon tau (IFN- $\tau$ ), previously known as the ovine trophoblast protein (oTP-1 or trophoblastin) was the first example of an "embryonic" IFN, found in ruminant species. It was temporarily and tissue-specifically secreted in substantial amounts by the elongating sheep conceptus. IFN- $\tau$ shares $70 \%$ sequence similarity with bovine and human IFN- $\omega$. Although developmentally induced, the IFN- $\tau$ molecule is considered to be an IFN, by its antiviral activity, its ability to bind to type I IFN receptors and induction of 2'-5'-oligoadenylate synthetase [67]. In spite of its IFN nature, the role of IFN- $\tau$ is not primarily antiviral. It is physiologically secreted by the early trophoblast and not found in any other physiological or pathological processes. It can be pointed out that its main role is a hormone like activity in early maternal recognition of pregnancy. Several authors [4, 40, $66]$ confirmed that indeed, IFN- $\tau$ inhibits secretion of luteolytic prostanglandins and allows a sustained progesterone supply by the corpus luteum, and therefore, maintenance of pregnancy in ruminants.

Because of its function, IFN- $\tau$ is analogous to the chorionic gonadotrophin (hCG) in early pregnancy in humans [65]. Similar molecules belonging to the IFN- $\tau$ multigenic family have also been found in cattle and other ruminant species.

In pigs, two IFN species, clearly different from IFN- $\tau$, were found to be developmentally induced and secreted by implanting embryos $[45,49]$. A weak secretion of IFN- $\boldsymbol{\gamma}$ was detected in in vitro developing human embryos, just before implantation 
[61]. Other evidence that IFN- $\gamma$ is secreted by the human villous syncytiotrophoblast and extravillous trophoblast in decidua during the first trimester of pregnancy was found, followed by a significant decline in secretion up to term pregnancy, where only a weak signal of IFN- $\gamma$ was detected in extravillous trophoblast in the decidua [63]. In mice, no IFNs or IFN-like activity was detected during early pregnancy [44].

The occurrence of embryonic IFNs therefore is not common to all mammalian species.

\subsection{Embryonic IFNs in pigs}

In the pig, which is related to ruminants in terms of conceptus development and type of implantation, enormous antiviral activity has been found at the time of blastocyst implantation [10]. Further analysis has revealed that two species are present in the uterine flushings and in the supernatants of conceptus-conditioned media between days $12-20$ of gestation. The predominant species was found to be an IFN- $\gamma$ [45, 49]. The other species was shown to be a novel type I interferon, IFN- $\delta$, previously known as sp-1 [48].

\subsubsection{Interferon delta (IFN- $\delta)$}

At the time of implantation, type I IFN has also been found to be secreted by the pig conceptus, on the basis of its seroneutralisation by an antiserum to human leucocytic IFN [45]. Physico-chemical analysis of recombinant IFN- $\delta$, expressed in insect cells, has confirmed a close relation of IFN- $\delta$ with other type I IFNs [60]. By analogy with ruminants, it was expected that this type I IFN could be IFN- $\omega$-like, but the results were negative. Cloning and sequencing of this unique IFN, co-expressed with IFN- $\gamma$, revealed a novel type I gene, distinctly related to the known type I IFNs (27-42\% homology). Like other type I IFN genes, this IFN gene is intronless [48]. The synthesis of IFN- $\delta$ is governed by one mRNA at about $1.3 \mathrm{~kb}$ [48]. The amino acid sequence of the IFN- $\delta$ molecule predicted a 170 amino acid long pre-protein and a putative signal peptide of 21 amino acid residues. The mature protein with 149 amino acid residues represents the shortest type I IFN known and was provisionally defined as the short-porcine IFN I (sp-1) [48]. More recently, the sp-1 IFN was accepted as a new member of the type I IFN family and named interferon delta (IFN- $\delta$ ). IFN- $\delta$ is coexpressed with IFN- $\gamma$ by the pig trophectoderm during the preimplantation period in much lower amounts than IFN- $\gamma$. Like IFN $-\gamma$, IFN- $\delta$ is secreted from the apical side of the trophoblast monolayer. Unlike IFN- $\gamma$, IFN- $\delta$ secretion is evenly distributed throughout the cytoplasm, suggesting a different secretory pathway [51]. As well as IFN- $\tau$, IFN- $\delta$ can be considered as a true trophoblastic interferon [51].

The characterisation of the IFN- $\delta$ molecule revealed that the active molecule is a single N-glycosylated monomer with an apparent $\mathrm{M}_{\mathrm{r}}$ of 19000 . Treatment with $\mathrm{N}$-glycosidase $\mathrm{F}$ produces a single polypeptide with an $\mathrm{M}_{\mathrm{r}}$ of 17000 [60]. Glycosylation most probably occurs at Asn-79 [60]. Physico-chemical analysis confirmed a close relationship with other type I IFN. IFN- $\delta$ is stable at a pH 2, thermolabile, able to renature after complete denaturation $(1 \%$ 2-mercaptoethanol, 1\% SDS and $5 \mathrm{M}$ urea). It is sensitive to reduction, showing that disulfide bonds are essential for bioactivity. Its specific activity is above $10^{8}$ $\mathrm{U} / \mathrm{mg}$, that is in the range of other type I IFN [60]. Surprisingly, unlike the other type I IFN, IFN- $\delta$ has a very basic pI (above 9 ), like type II IFN [51].

Binding experiments have shown that IFN $-\delta$ shares at least the major binding subunit of the type I IFN receptor on porcine cells [59]. IFN- $\delta$ is devoid of activity in human cells, which may be related to the absence of IFN- $\delta$ gene homology in humans (in the frame of the ligand-receptor co-evolution hypothesis) [51]. IFN- $\delta$ exhibits a 
synergistic antiproliferative activity with IFN- $\gamma$ on ST-cells, but not with other type I IFNs. This synergy might be another mean of amplification of bioactivity [51].

\subsubsection{Interferon gamma (IFN- $\gamma)$}

IFN- $\gamma$ is secreted by the pig embryo between days 12 and 20 of gestation in large amounts (up to $250 \mu \mathrm{g}$ per uterine horn), with the peak of synthesis at days 15 and 16. Strong IFN- $\gamma$ production by the pig preimplantation trophoblast appears to be a unique feature of this species [43].

Indirect immunofluorescence has revealed that IFN- $\gamma$ secretion is localised in the extraembryonic trophectoderm, the external monolayer of the trophoblast. The other constituents of the extra-embryonic membrane and the embryo itself, were negative in immunostaining, confirming that IFN- $\gamma$ is indeed secreted only by the trophectoderm [49]. The specific fluorescence was localised within the apical perinuclear cytoplasm of the trophoectoderm cells, in what seems to be a Golgi network. Trophoblast secretes IFN- $\gamma$ on its apical pole towards the uterine epithelium $[43,51]$. The mechanism by which expression of embryonic IFN- $\gamma$ is regulated, still remains unknown.

Northern blot analysis of mRNAs has established that IFN- $\gamma$ is actually synthesised by the conceptus. Hybridisation with a human IFN- $\gamma$ cDNA probe has revealed two distinct mRNA species of about 1.3 and $1.4 \mathrm{~kb}$ [49]. Both mRNAs are transcribed from the same unique gene for IFN- $\gamma$ [50] and translate into a single polypeptide. Unlike in lymphocytes, where only the longer $1.4 \mathrm{~kb}$ mRNA is found, the two trophoblastic mRNAs result from the presence, in the promoter sequence of the IFN- $\gamma$ gene, of two TATA boxes, which provide two initiation sites for transcription. It is possible that this tissue specific transcription mechanism represents a mean of amplification of IFN- $\gamma$ synthesis and se- cretion (Lefèvre, unpublished results). The conceptus secreted IFN- $\gamma$ protein is antigenically identical to its leucocytic counterpart, as proven by immunological assays with several antibodies raised against recombinant porcine IFN- $\gamma(\mathrm{rIFN}-\boldsymbol{\gamma})[43$, 49].

\section{BIOLOGY OF INTERFERON-GAMMA}

\subsection{Molecular and biochemical properties}

The first IFN- $\gamma$ gene was cloned and expressed in 1981 from activated human peripheral blood lymphocytes [30]. The porcine IFN- $\gamma$ gene was isolated and its structure and nucleotide sequence determined from a genomic library some years later [19]. The IFN- $\gamma$ molecule has little structural homology with type I IFNs. Unlike for type I IFNs, there is evidence for only one IFN- $\gamma$ gene in all mammalian species analysed. Activation of a porcine IFN- $\gamma$ gene leads to the synthesis of a single, 143 amino acid long mature polypeptide with a predicted $\mathrm{M}_{\mathrm{r}}$ of 16787 . The amino-terminus of the mature polypeptide was predicted to end with glutamine in natural porcine IFN- $\gamma$, but as for natural human IFN- $\gamma$ it is probably modified to pyroglutamate [41].

By analogy with human and mouse IFN- $\gamma$, porcine IFN- $\gamma$ is probably a dimer with a predicted molecular mass of 34000 for recombinant non glycosylated IFN- $\gamma$ $[1,76]$. Two polypeptides self-associate to form a homodimer, which seems to be the most active form in physiological conditions. Since the mature IFN- $\gamma$ polypeptide is devoid of cysteine residues, there is no disulphide bonds present, thus in the dimer, monomers are held together exclusively by non-covalent forces. The secondary protein structure is primarily $\alpha$ helical, with six helices (A-F) in each subunit that comprise 
approximately $62 \%$ of the structure. There is no $\beta$ sheet [22].

In all mammalian species, IFN- $\gamma$ is secreted mainly as a glycoprotein. There are two potential sites of $\mathrm{N}$-glycosylation (Asn-X-Thr/Asn-X-Ser) in each of the monomeric units that may be variably occupied by N-linked glycans. The glycans of the natural human IFN- $\gamma$ molecule have been demonstrated to consist of complex sialylated bi-antennary structures with some heterogeneity in the content of sialic acid and fucose [36, 77].

Natural leucocytic porcine IFN- $\gamma$ (LePoIFN- $\gamma$ ) consists of 4 heterogeneous glycoforms with apparent molecular weights between 17500 and 24800 (Fig. 3). This macro-heterogeneity arises as a consequence of attachment of various $\mathrm{N}$-glycans to the N-glycosylation site of the IFN- $\gamma$ molecule rather than polypeptide truncation, since only two polypeptide chains (Mw: 16000 and 14 000) were present after deglycosylation [9]. Conceptus secreted trophoblastic IFN- $\gamma$ shows less variability in the sugar moiety but severe truncations in the protein structure. Only two glycoforms were visible (Mw: 22500 and 18000 ) that, after treatment with $\mathrm{N}$-glycosydase $\mathrm{F}$ resolved into one main truncated polypeptide chain that may correspond to the truncation of about 20 amino acids (Fig. 3). In the uterine flushings, an even more proteolytically cleaved form of trIFN- $\gamma$ (Mw: 12 500) was found, suggesting that only the truncated trIFN- $\gamma$ molecule is accessible to the maternal endometrium [8]. Unlike for human IFN- $\gamma$, no non-glycosylated form has been found in leucocytic or trophoblastic PoIFN- $\gamma$, indicating a possible species specific posttranslational processing of the IFN- $\gamma$ molecule. These results clearly show that in the pig, trophoblastic IFN- $\gamma$ differs from its



Figure 3. Schematic resolution of trIFN- $\gamma$ in SDS-PAGE, before and after deglycosylation, by comparison with LeIFN $-\gamma \cdot \operatorname{trIFN}-\gamma$ was produced in the supernatant of cultured conceptuses. Leucocytic IFN- $\gamma($ LeIFN- $\gamma)$ was obtained in the supernatant of pig blood leukocytes treated with Phytohemagglutinin and incubated for $48 \mathrm{~h}$. Both IFNs were produced in the presence of ${ }^{35}$ S-Methionine, then immunoprecipitated with a rabbit antiserum to porcine IFN- $\gamma$. Pellets were treated or mock-treated overnight with $\mathrm{N}$-glycosydase F. Resulting precipitates were electrophoresed on a $12.5 \%$ acrylamide gel. 
leucocytic counterpart in glycosylation and C-terminal post-translational processing $[8,9]$. These differences may well arise due to unusual cell sources of trIFN- $\gamma$ secretion, as it has been shown for recombinant glycosylated human IFN- $\gamma$, indicating that posttranslational processes are strongly dependent on the eukaryotic cell type used as expression systems [41].

Leucocytic PoIFN- $\gamma$, like HuIFN- $\gamma$, is a very basic protein. Its calculated $\mathrm{pI}$ is 9.87 due to its high content in basic amino acid residues (Lys, Arg), including a C-proximal cluster RKRKR. An experimental pI of small portions of LePoIFN- $\gamma$ molecules appears to be approximately one $\mathrm{pH}$ unit lower $(8.4-8.8)$ [8, 42]. By analogy with HuIFN- $\gamma$, a shift from the theoretical value is due to a different content of terminal sialic acid that shifts $\mathrm{pI}$ to lower $\mathrm{pH}$ values [21].

Surprisingly, the pI of trIFN- $\gamma$ could not be experimentally determined. It seems that a charge of the protein molecule is masked by carbohydrates. It could be that this property is relevant to a particular bioavailability and/or function in the uterine sphere.

\subsection{Main functions of IFN- $\gamma$}

IFN- $\gamma$ stimulates the induction of a variety of genes that function in the immune response and have several other functions. The major biological functions of IFN- $\gamma$ are summarised in Table II.

\subsubsection{Antiviral activity}

IFN- $\gamma$ shares a general property of all IFNs, to induce transient resistance to a broad range of pathogens. Although its role as an antiviral agent was initially considered as minor in comparison with type I IFNs, studies on knock-out mice have shown its importance in antiviral host defence [38]. IFN- $\gamma$ efficiency of virus replication inhibition depends on the virus type (reovirus and vaccinia virus displayed a higher sensitivity to IFN- $\gamma$ than vesicular stomatitis virus or encephalomyocarditis virus) [29]. It has been accepted that IFN- $\gamma$ potentiates IFN- $\alpha / \beta$ activity as a first line of defence, secondarily amplified by the antiviral activities of IFN- $\gamma[3,37,39]$.

\subsubsection{Antimicrobial activity}

Studies on mice with disrupted IFN- $\gamma$ genes revealed the importance of IFN- $\gamma$ in host defence against other intracellular pathogens like Listeria monocytogenes, Mycobacterium sp., Legionella pneumophila and others $[15,18,38]$. Mice deficient in IFN- $\gamma$ or IFN- $\gamma$ receptors have impaired production of macrophage antimicrobial products (like NO) and reduced expression of MHC II antigens. Concerning an anti-infectious activity, this antibacterial effect might well be one of the main specific activities of IFN- $\gamma$.

\subsubsection{Immunomodulation}

One of the major physiologic roles of IFN- $\gamma$ is its ability to regulate MHC class I and class II protein expression on a variety of immunologically important cell types (macrophages, monocytes, endothelial and epithelial cells). Whereas IFN- $\alpha$ and IFN- $\beta$ can also up-regulate MHC class I antigens, they are not inducers of MHC class II proteins. At the functional level, IFN- $\gamma$ dependent up-regulation of MHC gene expression is an important step in promoting antigen presentation during the inductive phase of the immune response $[17,24$, 78]. IFN- $\gamma$ also increases expression of high affinity Fc (FcyRI) receptors on monocytes and macrophages, and thereby enhances the capacity of these cells to participate in antibody dependent cellular cytotoxicity reactions. The effect of IFN- $\gamma$ is often synergistically enhanced by tumour necrosis factors (TNF) [24]

Although monocyte/macrophages are a prime cellular target for IFN- $\gamma$ under physiological conditions, IFN- $\gamma$ exerts its effects on other cells of the immune system. 
Table II. Major biological functions of IFN- $\gamma$.

\begin{tabular}{|c|c|c|c|c|}
\hline Function & Effect & Mechanism of action & Cells & References \\
\hline ANTIVIRAL & $\begin{array}{l}\text { Inhibition of virus } \\
\text { replication. }\end{array}$ & $\begin{array}{l}\text { Induction of } \\
\left(2^{\prime}-5 \text { ')-oligoadenylate }\right. \\
\text { synthethase, } \\
\text { protein kinase, } \\
\text { Mx1 protein. }\end{array}$ & Most cells & $\begin{array}{l}{[3]} \\
{[37]} \\
{[39]}\end{array}$ \\
\hline $\begin{array}{l}\text { ANTIMICROBIAL } \\
\text { (antibacterial, } \\
\text { antifungal, } \\
\text { antiparasitic) }\end{array}$ & $\begin{array}{l}\text { Killing of microbes by } \\
\text { macrophage toxic pro- } \\
\text { duction (NO, } \mathrm{H}_{2} \mathrm{O}_{2} \text {, } \\
\text { 2,3-dioxygenase, etc.). } \\
\text { Inhibition of cellular } \\
\text { invasion and intracellular } \\
\text { replication of microbes). }\end{array}$ & $\begin{array}{l}\text { Enhancement of inducible } \\
\text { NO oxidase that promotes } \\
\text { pathogen iron loss, } \\
\text { augmentation of oxidative } \\
\text { burst and enhancing the } \\
\text { expression of cytochrome } \\
\text { b558, } \\
\text { activation of gene } \\
\text { expression by induction of } \\
\text { transcription factor NF- } \mathrm{B} \text {, } \\
\text { leading to the translation of } \\
\text { immunoregulatory proteins, } \\
\text { induction of indoleamine } \\
\text { 2,3-dioxygenase that } \\
\text { breaks down L-tryptophane } \\
\text { and decreases intracelullar } \\
\text { ion concentration. }\end{array}$ & Most cells & $\begin{array}{l}{[3]} \\
{[18]} \\
{[78]}\end{array}$ \\
\hline $\begin{array}{l}\text { SPECIFIC } \\
\text { IMMUNITY }\end{array}$ & Activation of host defence & $\begin{array}{l}\text { Induction of MHC class II } \\
\text { antigens, } \\
\text { Up-regulation of MHC } \\
\text { class I antigens, } \\
\text { Up-regulation of Fc } \\
\text { receptors, } \\
\text { Induction of Ig switch. }\end{array}$ & $\begin{array}{l}\text { Many tissues, } \\
\text { Most cells, } \\
\text { Macrophages, } \\
\text { Lymphocytes, } \\
\text { B lymphocytes }\end{array}$ & $\begin{array}{l}{[17]} \\
{[24]} \\
{[78]}\end{array}$ \\
\hline $\begin{array}{l}\text { NONSPECIFIC } \\
\text { IMMUNITY }\end{array}$ & Activation of host defence & $\begin{array}{l}\text { Up-regulation of IL-1, CSF, } \\
\text { Down-regulation of IL-4, } \\
\text { Up-regulation of TNF, } \\
\text { Down-regulation of } \\
\text { complement C3b receptor. }\end{array}$ & $\begin{array}{l}\text { Macrophages, } \\
\text { T lymphocytes, } \\
\text { Macrophages, } \\
\text { Macrophages }\end{array}$ & $\begin{array}{l}{[17]} \\
{[78]}\end{array}$ \\
\hline ADHESION/MATRIX & $\begin{array}{l}\text { Augmentation of cell } \\
\text { adherence }\end{array}$ & $\begin{array}{l}\text { Up-regulation of ICAM-1, } \\
\text { Down regulation of } \\
\text { collagen, } \\
\text { Up-regulation of } \\
\text { fibronectin. }\end{array}$ & $\begin{array}{l}\text { Endothelial } \\
\text { cells, } \\
\text { Fibroblasts, } \\
\text { Macrophages }\end{array}$ & $\begin{array}{l}{[24]} \\
{[39]}\end{array}$ \\
\hline $\begin{array}{c}\text { CELL GROWTH } \\
\text { AND } \\
\text { DIFFERENTIATION }\end{array}$ & $\begin{array}{l}\text { Direct inhibition of cancer } \\
\text { cell multiplication, } \\
\text { Activation of killer } \\
\text { leucocytes }\end{array}$ & $\begin{array}{l}\text { Up or down regulation of } \\
\text { c-myc oncogene, } \\
\text { Down regulation of EGF } \\
\text { receptors } \\
\text { Induction of MHC class II } \\
\text { antigens }\end{array}$ & $\begin{array}{l}\text { Many cells, } \\
\text { Epithelial cells, } \\
\text { Cells of the im- } \\
\text { mune system }\end{array}$ & $\begin{array}{l}{[3]} \\
{[46]} \\
{[78]}\end{array}$ \\
\hline
\end{tabular}

It regulates $\mathrm{IgG}$ switching in B-cells and antagonises the ability of IL-4 to induce MHC class II expression on murine B-cells. Its activity in host defence exerts also through the up-regulation of IL-1, CSF and down-regulation of $\mathrm{C} 3 \mathrm{~b}$ complement receptors by macrophages and fibroblasts $[24,78]$.

\subsubsection{Interactions with cellular adhesion molecules}

IFN- $\gamma$ increases the expression of several surface proteins (like ICAM-1), thereby promoting cell adherence [62].

Recently, it was found that HuIFN- $\gamma$ binds with comparable affinity to heparan 
sulphate and heparin - via sulphated groups of their carbohydrate side chains - present in the cellular matrix [55]. It was found that basement membranes play an important role in cytokine activity [54]. Binding of IFN- $\gamma$ to glycosaminoglycans (heparin and heparan sulphate) occurs through a specific cluster of very basic amino acid residues (between positions 125 and 131) from the C-terminus of the IFN- $\gamma$ molecule with a very high affinity $\left(\mathrm{K}_{\mathrm{d}}=10^{-9} \mathrm{M}\right)[53,56]$. This binding is not based on a simple electrostatic interaction and appears to be specific, since IFN- $\gamma$ does not bind to other types of polyanionic glycosaminoglycans, like dermatan or chondroitin sulphate. Binding of IFN- $\gamma$ to heparan sulphate and heparin is of important biological relevance as a local source of soluble IFN via heparan sulphate in a basement membrane. A complex of heparan sulphate/IFN- $\gamma$ is fully active, indicating that the $\mathrm{C}$-terminus is not directly involved in the interaction with cellular receptors, a result that is contradictory to the results published by Axelrod et al. and Szente and Johnson [2, 71]. Heparan sulphate and heparin prevent $\mathrm{C}$-terminus proteolysis of the IFN- $\gamma$ molecule, therefore preserving its bioactivity by directed proteolysis [20, 53]. However, there are some publications showing that heparin and heparan sulphate inhibit anti-parasitic and anti-proliferative activity of IFN- $\gamma$ and diminish IFN- $\boldsymbol{\gamma}$ induction of MHC class II antigens, favouring a blocking effect of heparin on IFN- $\gamma$ binding to its cellular receptor $[13,14]$.

\subsubsection{Effect on cell growth and differentiation}

In addition, this multipotent cytokine exerts various other functions related to cell growth and differentiation, and has an antitumour activity in humans and animals.

IFN- $\gamma$ is suppressive for early hematopoietic progenitor cell development when acting as a single agent, but when it is present with other cytokines (IL-3, stem cell factor, etc.) it may enhance progenitor cell development [78]. Experiments on IFN- $\gamma$ knock-out mice demonstrate that IFN- $\gamma$ has an important inhibitory role in $\mathrm{T}$ cell proliferation [15]. The relationship between NK-activity and IFN- $\gamma$ is even more complex. It was demonstrated that IFN- $\gamma$ treated target cells became less sensitive to NK-cytotoxicity due to enhanced expression of MHC class I molecules [24]. Inversely, tumour cells that expressed more MHC class I molecules became more susceptible to cytolytic activity of NK cells $[17,24,39,78]$. Recently, it has been shown that IFN- $\gamma$, developmentally induced in pigs and humans, may have important functions in reproduction $[45,49,63]$. IFN- $\gamma$ functionally participates in diverse, somehow controversial pathways, such as precursor cell development and inhibition, clonal activation and tolerance, induction, cellular apoptosis and enhanced survival, cellular differentiation, tumour rejection or metastasis, proinflammatory and antiinflammatory states. Its role in promoting or inhibiting the maturation/differentiation of each of the immune effector cell populations highlights the importance of this protein in the immune response and multitude of cellular, hormonal and other networks.

\section{POSSIBLE ROLE(S) OF PORCINE EMBRYONIC IFN- $\gamma$}

IFN- $\gamma$ was found in the uterus in the first trimester of pregnancy in humans, another mammalian species known to express developmentally induced IFN- $\gamma$. It is expressed simultaneously with IFN- $\gamma$ R by the trophoblast, strongly suggesting an autocrine activity [63]. In the pig, there is no autocrine activity predicted, since trophoblast do not possess any receptors for both IFNs at the time of IFN- $\gamma$ and $\delta$ expression [12]. The possible role(s) of embryonic IFN- $\gamma$ found in the pig and in humans is at present only speculative [43]. 


\subsection{Autocrine/paracrine activity}

The first question to answer was whether foetal trophoblast or maternal endometrial tissue is the main target of IFN- $\gamma$ action. In the pig, there is evidence that at the time of implantation (between day $12-16$ of gestation) the trophoblast is extremely sensitive to viral infection [12]. Further results indicate that IFN- $\gamma$ does not induce antiviral resistance or (2'-5')oligoadenylate synthetase activity in the trophoblast, therefore no autocrine function can be established. On the contrary, maternal tissue shows various degrees of susceptibility to the antiviral activity of trophoblastic IFN. IFN- $\gamma$ has been shown to be considerably more antiviral on primary glandular epithelial cells, while IFN- $\delta$ is more effective on primary stromal fibroblasts [12]. Since antiviral resistance can be established in endometrial cell lines, its paracrine activity was considered. The uterine epithelium was considered the most probable, and perhaps the only target of trophoblastic IFN- $\gamma$, as well as IFN- $\delta$ (since not even trace amounts of IFN- $\gamma$ could be detected in the uterine vein) $[12,52]$.

Recently, experiments indicating that PoIFN $\gamma \mathrm{R}$ appear around day 16 of gestation suggest a possible, delayed autocrine effect of trophoblastic IFN- $\gamma$ [11].

\subsection{Antiviral activity}

Although there is no direct antiviral effect of embryonic IFN- $\gamma$ on the trophoblast in the pig and since no antiviral state could be established by the Vesicular Stomatitis virus (VSV) and Transmissible Gastroenteritis virus (TGEV) in the trophoblastic vesicles, its protective role against viral infections should be considered, since IFN- $\gamma$ anti-viral action could be established in the uterine epithelium $[12,43]$. In humans, it cannot be excluded that trophoblastic IFN- $\gamma$ may promote the protection of the conceptus from microorganisms which are transplanted across the placental barrier (rubella virus, cytomegalovirus, poliovirus), having deleterious effects [63]. Such IFN- $\gamma$ may substitute embryonic IFN- $\gamma$, produced by a few $\mathrm{T}$ lymphocytes in the human foetus, causing its unusual susceptibility to intracellular pathogens and virus infections [17].

\subsection{Hormone-like activity}

Published data demonstrate that, unlike in ruminants, porcine trIFN- $\gamma$ does not contribute to the maintenance of corpus luteum (CL) functions (the so called "antiluteolytic effect") known for IFN- $\tau$ in ruminants [52].

Oestrogens appear to be the main or only effectors of maternal recognition of pregnancy in pigs, although it remains possible that IFNs could synergise with oestrogens, released by the conceptus between days 15-18, towards the extension of the CL lifespan [27]. Treatment with oestrogens between days 11 and 15 after oestrus, maintains the luteal lifespan in nonpregnant sows for up to 300 days. The fact that infusion of total conceptus secretory proteins in the uterus of cyclic sows did not prolong luteal lifespan, supports the above statement [43].

\subsection{Immunoregulation}

In view of the major role of "adult" leucocytic IFN- $\gamma$ as an immunomodulator and antiproliferative/cytotoxic agent, the question arises whether embryonic IFN- $\gamma$ could exert such functions in the uterine sphere, acting locally to an amplified extent (because of the large concentrations found between days 12 and 20 of pregnancy, which is the time of its secretion). The hypothesis that the function of the embryonic PoIFN- $\gamma$ might be immunoregulatory, was put forward by Engelhardt and her colleagues, after observations that the number of uterine lymphocytes decrease in the luminal epithelium and increase in the endometrial stroma at sites of conceptus 
attachment, and that dispersed endometrial cells exhibit a pregnancy-specific increase in NK-lytic activity. They postulated that the trophoblast may contribute to this event through secreted IFN- $\gamma$, if it could cross the maternal endometrium [23].

It has been demonstrated that in humans and mice the preimplantation trophoblast does not express classical transplantation antigens. It has been established that the syncytiotrophoblast is resistant to IFN- $\gamma$ mediated induction of MHC class I molecule expression [34]. The role of IFN- $\gamma$ and IFN $\gamma \mathrm{R}$ expressed during implantation and in early stages of gestation may be to enhance protection of the conceptus. A key element for a successful foetal allograft is the degree of MHC class I antigen expression by trophoblast cells. In humans, there are non-classical MHC class I molecules that may protect non-villous trophoblast from lysis by maternal decidual NK cells. IFN- $\gamma$ could have a role in the enhanced protection against NK cytolytic activity, since it was shown that it up-regulates the MHC class I antigens in murine and human trophoblast cell lines [63].

In the pig, $\beta-2$ microglobulin was expressed at the apex of the trophectoderm between days 6-12, suggesting that $\mathrm{MHC}$ class I antigens are expressed. However, the finding that the pig preimplantation trophoblast has no functional IFN $-\gamma$ receptors, rules out the modulation of trophoblast MHC antigens by IFN- $\gamma$ [12]. It is possible that trophoblastic IFN- $\gamma$ in pigs serve as an activator of cells with NK activity in the endometrial mucosa [23], if it could reach the endometrial stroma.

\subsection{Possible role in conceptus implantation}

Very few data can be found, defining a possible role of IFN- $\gamma$ during conceptus implantation. There is evidence that exogeneously added recombinant IFN- $\gamma$ arrests human embryo development in vitro [35]. In addition, IFN- $\gamma$ was found to retard mouse foetal growth or to induce abortion in vivo. Others indicate that IFN- $\gamma$ inhibits trophoblast outgrowth and causes inhibition of plasma membrane mobility in mouse embryo cells $[33,64]$.

More likely, IFN- $\gamma$ could be a helper substance for other factors (that is integrins, heparan sulphate proteoglycans, etc.) necessary for implantation. In several experimental models, it was shown that IFN- $\gamma$ increases the endometrial epithelial barrier permeability of the basolateral surface and inhibits the proliferation of human endometrial cells $[73,75]$. IFN- $\gamma$ expressed and secreted by $\mathrm{T}$ cells and lymphoid aggregates induces the human leukocyte antigen DR (HLA-DR) adjacent to the endometrial epithelium, which supports a role of IFN- $\gamma$ in the induction of lympho- epithelial interactions [74].

Therefore, in humans, IFN- $\boldsymbol{\gamma}$ may be involved in regulating epithelial growth and interactions between the epithelium and lymphatic tissues [31, 72, 74]. In mice, knock-out experiments showed that IFN- $\gamma$ is not required for normal embryonic development or the generation of a specific immune response [38]. These findings confirmed previous results showing that no IFN (type I or type II) can be detected during early pregnancy in mice [44].

In the pig, the environment into which trIFNs are secreted limits their action mainly to the maternal endometrium, since it has been shown that there is no autocrine effect on the trophoblast at the time of trophoblast implantation, and no trIFN- $\gamma$ has been found in uterine veins $[12,52]$. As in pigs there is no trophoblast invasion of the maternal endometrium, an antiproliferative or cytotoxic effect of trIFN- $\gamma$ or IFN- $\delta$ is rather unlikely.

On the contrary, based on the known depolarising effect of IFN- $\gamma$ on the human intestinal cell line [75] and because the 
maternal endometrial tissue moderately responds to IFN- $\gamma$, as shown by antiviral activity on primary glandular endometrial cells it is possible that either trIFN- $\gamma$ or IFN- $\delta$, or both, contribute to a remodelling of the endometrial epithelium, affecting its polarity and receptivity to the trophoblast, thus favouring trophoblast attachment [12].

\section{CONCLUSION}

Embryonic interferons, found to be secreted in early pregnancy by the trophoblast in several ungulate species, have considerably enlarged our view of interferon induction and functions: they are not produced in response to pathogens or antigens, but their induction is developmentally programmed. Physiological induction in embryonic tissue has enriched the type I IFN gene family with two new members: IFN- $\tau$ found in sheep and cattle, and IFN- $\delta$ identified in pigs. Based on the hormone-like function of ovine IFN- $\tau$ on maternal recognition of pregnancy (MRP), trIFNs may exert other functions than that of anti-infectious agents.

The porcine trophoblast is so far the only tissue that simultaneously secretes type I (delta) and type II (gamma) IFN, the latter being produced in substantial amounts. As shown in this review, the physiological role of these IFN in Suidae most probably differs from that found in ruminants, since it has been shown that conceptus - derived oestrogens are the main effectors of MRP, and because it has been experimentally shown that TrIFNs per se do not affect progesterone levels in cyclic gilts (and hence do not mimic MRP).

Focusing on porcine trophoblastic IFN- $\gamma$, there is no doubt that it will be difficult to delineate its main function in pregnancy. We favour two main possibilities, that are not exclusive. Firstly, due to the known biological roles of leucocytic IFN- $\gamma$, trIFN- $\gamma$ could mainly act as an anti- infectious agent, providing a healthy environment for implanting embryos. Since trIFN- $\gamma$ has no autocrine effect, its protective activity would be established either by a direct effect on the endometrial epithelium, or by enhancing the immune reactivity of uterine lymphoid cells. In the latter case, one has to assume that IFN- $\gamma$ does cross the tight uterine epithelial barrier. This possibility could be explored by the study of MHC class II antigen induction in uterine stroma. Secondly, trIFN- $\gamma$ could remain confined to the uterine lumen and be a direct effector of uterine epithelial depolarisation via the apical side of the luminal epithelium, leading to partial or profound remodelling (depolarisation or other effects) of this maternal tissue, a condition necessary for conceptus implantation.

Further investigations, especially the analysis of different markers in pregnant pig uteri, and studies in uterine cell culture models, are hoped to provide a better understanding of the trophoblastic IFNs effects in early pregnancy.

\section{REFERENCES}

[1] Arakawa T., Hsu Y.R., Chang D., Stebbing N., Altrock B., Structure and activity of glycosylated human interferon- $\gamma$, J. Interferon Res. 6 (1986) 687-695.

[2] Axelrod A., Gibbs V.C., Goeddel D.V., The Interferon- $\gamma$ receptor extracellular domain, J. Biol. Chem. 22 (1994) 15533-15539.

[3] Baron S., Tyring S.K., Fleischmann R.W. Jr., Coppenhaver D.H., Niesel D.W., Klimpel G.R., Stanton J., Hughes T.K., The interferons, mechanisms of action and clinical applications, J. Am. Med. Assoc. 266 (1991) 1375-1383.

[4] Bazer F.W., Johnson H.M., Type I conceptus interferons: maternal recognition of pregnancy signals and potential therapeutic agents, Am. J. Reprod. Immunol. 26 (1991) 19-22.

[5] Bjorkman N., Dantzer V., Leiser R., Comparative placentation in laboratory animals - a review, Scand. J. Lab. Anim. Sci. 16 (1989) 129-158.

[6] Bowen J.A., Bazer F.W., Burghardt R.C., Spatial and temporal analyses of integrin and muc-1 expression in porcine uterine epithelium and 
trophoectodern in vivo, Biol. Reprod. 55 (1996) 1098-1106.

[7] Burghardt R.C., Bowen J.A., Newton G.R., Bazer F.W., Extracellular matrix and the implantation cascade in pigs, J. Reprod. Fert. Suppl. 52 (1997) 151-164.

[8] Cencič A., Biochemical and functional study of an embryonic interferon-gamma secreted by the porcine trophoblast, Thèse de Doctorat en Sciences, Université Paris-Sud, 5 décembre 2000.

[9] Cencič A., Lefèvre F., Koren S., La Bonnardière C., Tetracycline-controlled expression of glycosylated porcine interferon- $\gamma$ in mammalian cells, Anim. Biotechnol. 10 (1999) 63-79.

[10] Cross J.C., Roberts R.M., Porcine conceptuses secrete an interferon during the preattachment period of early pregnancy, Biol. Reprod. 40 (1989) 1109-1118.

[11] D'Andrea S., La Bonnardière C., Cloning of the porcine interferon- $\gamma$ receptor and its foetoendometrial expression in early pregnancy, Mol. Reprod. Dev. 51 (1998) 225-234.

[12] D’Andrea S., Chousterman S., Fléchon J.E., La Bonnardière C., Paracrine activities of porcine trophoblastic interferons, J. Reprod. Fertil. 102 (1994) 185-194.

[13] Daeubener W., Nockemann S., Gutsche M., Hadding U., Heparin inhibits the antiparasitic and immune modulatory effects of human recombinant interferon- $\gamma$, Eur. J. Immunol. 25 (1995) 688-692.

[14] Daeubener W., Gutsche, M., Nockemann S., Mackenzie C., Seghrouchni S., Hadding U., Protamine enhances the activity of human recombinant interferon- $\gamma$, J. Interferon Cytokine Res. 16 (1996) 531-536.

[15] Dalton D.K., Pitts-Meck S., Keshan S., Figari I.S., Bradley A., Stewart T.A, Multiple defects of immune cell function in mice with disrupted interferon-gamma genes, Science 259 (1993) 1739-1742.

[16] Dantzer V., Electron microscopy of the initial stages of placentation in the pig, Anat. Embryol. 172 (1985) 281-293.

[17] De Maeyer E., De Maeyer-Guignard J., Interferons and other regulatory cytokines, John Wiley \& sons, New York, 1988.

[18] Degre M., Interferons and other cytokines in bacterial infections, J. Interferon Cytokine Res. 16 (1996) 417-426.

[19] Dijkmans R., Vandenbroeck K., Beuken E., Billiau A., Sequence of the porcine interferongamma (IFN-gamma) gene, Nucleic Acids Res. 18 (1990) 4259.

[20] Dobeli H., Gentz R., Jucker W., Garotta G., Hartmann D.W., Hochuli E., Role of the carboxy-terminal sequence on the biological activity of human immune interferon (IFN- $\gamma$ ), J. Biotechnol. 7 (1988) 199-216.
[21] Dorner F., Scriba M., Weil R., Interferon: Evidence for its glycoprotein nature, Proc. Natl. Acad. Sci. USA 70 (1973) 1981-1985.

[22] Ealick S.E., Cook W.J., Kumar S.V., Carson M., Nagabhushan T.L., Trotta P.P., Bugg C.E., Three-dimensional structure of recombinant human interferon- $\gamma$, Science 252 (1991) 689-701 .

[23] Engelhardt H., Croy B.A., King G.J., Role of uterine immune cells in early pregnancy in pigs, J. Reprod. Fert. Suppl. 52 (1997) 115-131.

[24] Farrar M.A., Schreiber R.D., The molecular cell biology of interferon- $\gamma$ and its receptor, Annu. Rev. Immunol. 11 (1993) 571-611.

[25] Geisert R.D., Yelich J.V., Regulation of conceptus development and attachment in pigs, J. Reprod. Fert. Suppl. 52 (1997) 133-149.

[26] Geisert R.D., Renegar R.H., Thatcher W.W., Roberts R.M., Bazer F.W., Establishment of pregnancy in the pig. I. Interrelationships between preimplantation development of the pig blastocyst and uterine endometrial secretions, Biol. Reprod. 27 (1982) 925-939.

[27] Geisert R.D., Zavy M., Wettemann R.P., Biggers B.G., Length of pseudopregnancy and pattern of uterine protein release as influenced by time and duration of oestrogen administration in the pig, J. Reprod. Fert. 79 (1987) 163-172.

[28] Geisert R.D., Zavy M.T., Moffatt R.J., Blair R.M., Yellin T., Embryonic steroids and the establishment of pregnancy, J. Reprod. Fert. Suppl. 40 (1990) 293-305.

[29] Goodbourn S., Didcock L., Randall R.E., Interferons: cell signalling, immune modulation, antiviral responses and virus countermeasures, $\mathrm{J}$. Gen. Virol. 81 (2000) 383-390.

[30] Gray P.W., Leung D.W., Pennica D., Yelverton E., Najarian R., Simonsen C.C., Derynck R., Sherwood P.J., Wallace D.M., Berger S.L., Levinson A.D., Goeddel D.V., Expression of human immune interferon cDNA in $E$. coli and monkey cells, Nature 295 (1982) 503-508.

[31] Guidice L.C., Growth factors and growth modulators in human uterine endometrium: their potential relevance to reproductive medicine, Fertil. Steril. 61 (1994) 1-17.

[32] Guillomot M., Fléchon J.E., Leroy F., Blastocyst development and implantation, in: Thibault $\mathrm{C}$., Levasseur M.C., Hunter R.H.F. (Eds.) Reproduction in mammals and man, Ellipses, Paris, 2001.

[33] Haimovici F., Hill J.A., Anderson D.J., The effects of soluble products of activated lymphocytes and macrophages on blastocyst implantation events in vitro, Biol. Reprod. 44 (1991) 69-75.

[34] Hampton J., McLaughlin P.J., Johnson P.M., Low-affinity receptors for tumour necrosis factor- $\alpha$, interferon- $\gamma$ and granulocyte-macrophage colony-stimulating factor are expressed on human 
placental syncytiotrophoblast, Immunology 79 (1993) 485-490.

[35] Hill J.A., Haimovici F., Anderson D.J., Products of activated lymphocytes and macrophages inhibit mouse embryo development in vitro, $\mathrm{J}$. Immunol. 139 (1987) 2250-2254.

[36] Hooker A., James D., The glycosylation heterogeneity of recombinant human IFN- $\gamma$, J. Interferon Cytokine Res. 18 (1998) 287-295.

[37] Horisberger M.A., Virus-specific effects of recombinant porcine interferon- $\gamma$ and the induction of Mx proteins in pig cells, J. Interferon Cytokine Res. 12 (1992) 439-444.

[38] Huang S., Hendriks W., Althage A., Hemmi S., Bluethmann H., Kamijo R., Vilcek J., Zinkernagel R.M., Aguet M., Immune response in mice that lack the interferon- $\gamma$ receptor, Science 259 (1993) 1742-1745.

[39] Ljzermans J.N.M., Marquet R.L., Interferongamma: a Review, Immunobiology 179 (1989) 456-473.

[40] Imakawa K., Anthony R.V., Kazemi M., Marotti K.R., Polites H.G., Roberts R.M., Interferonlike sequence of ovine trophoblast protein secreted by embryonic trophectoderm, Nature 330 (1987) 377-379.

[41] James D.C, Goldman M.H., Hoare M., Jenkins N., Oliver R.W.A., Green B.N., Freedman R.B., Post-translational processing of recombinant human interferon- $\gamma$ in animal expression systems, Protein Sci. 5 (1996) 331-340.

[42] Karpov A.V., Ivanenko V.K., Kishko I.G., Spivak N.I., Dumanski V.D., The isolation and purification of porcine IFN- $\gamma$, Vopr. Virusol. 38 (1993) 78-81.

[43] La Bonnardière C., Nature and possible functions of interferons secreted by the pre-implantation pig blastocyst, J. Reprod. Fert. Suppl. 48 (1993) 157-170.

[44] La Bonnardière C., No detection of interferon- $\gamma$ activity during early pregnancy in the mouse, Am. J. Reprod. Immun. 30 (1993) 26-31.

[45] La Bonnardière C., Martinat-Botte F., Terqui M., Lefèvre F., Zouari K., Martal J., Bazer F.W., Production of two species of interferon by Large White and Meishan pig conceptuses during the peri-attachment period, J. Reprod. Fertil. 91 (1991) 469-478.

[46] La Bonnardière C., Lefèvre F., Charley B., Interferon response in pigs: molecular and biological aspects, Vet. Immunol. Immunopathol. 43 (1994) 29-36.

[47] Laloraya M., Fluidity of the phospholipid bilayer of the endometrium at the time of implantation of the blastocyst - a spin label study, Biochem. Biophys. Res. Commun. 167 (1990) 561-567.

[48] Lefèvre F., Boulay V., A novel and atypical type one interferon gene expressed by trophoblast during early pregnancy, J. Biol. Chem. 268 (1993) 19760-19768.
[49] Lefèvre F., Martinat-Botte F., Guillomot M., Zouari K., Charley B., La Bonnardière C., Interferon-gamma gene and protein are spontaneously expressed by the porcine trophoectoderm early in gestation, Eur. J. Immunol. 20 (1990) 2485-2490.

[50] Lefèvre F., Boulay V., La Bonnardière C., IFN- $\psi$ : a new type one embryonic IFN expressed during early pregnancy, J. Interferon Res. 12 (1992) (Suppl.1) S186.

[51] Lefèvre F., Guillomot M., D’Andrea S., Battegay S., La Bonnardière C., Interferon-delta: The first member of a novel type I interferon family, Biochimie 80 (1998) 779-788.

[52] Lefèvre F., Martinat-Botte F., Locatelli A., Niu P.D., Terqui M., La Bonnardière C., Intrauterine infusion of high doses of pig trophoblast interferons has no antiluteolytic effect in cyclic gilts, Biol. Reprod. 58 (1998). 1026-1031.

[53] Lortat-Jacob H., Grimaud J.A., Interferon gamma C-terminal function: new working hypothesis, Cell. Molec. Biol. 37 (1991) 253-260.

[54] Lortat-Jacob H., Grimaud J.A., La matrice extracellulaire: du tissu de soutien à la regulation des cytokines, Pathol. Biol. 42 (1994) 612-620.

[55] Lortat-Jacob H., Kleinman H.K., Grimaud J.A., High-affinity binding of interferon- $\gamma$ to a basement membrane complex (matrigel), J. Clin. Invest. 87 (1991) 878-883.

[56] Lortat-Jacob H., Turnbull J.E., Grimaud J.A., Molecular organization of the interferon- $\gamma$ binding domain in heparan sulphate, Biochem. J. 310 (1995) 497-505.

[57] Mattson B.A., Overstrom E.W., Albertini D.F., Transitions in trophectoderm cellular shape and cytoskeletal organization in the elongating pig blastocyst, Biol. Reprod. 42 (1990) 195-205.

[58] Mullins D.E., Bazer F.W., Roberts R.M., Secretion of a progesterone-induced inhibitor of plasminogen-activator by the porcine uterus, Cell 20 (1980) 865-872.

[59] Niu P.D., Lefèvre F., La Bonnardière C., Atypical spI interferon binds on porcine cells to a major component of type I interferon receptor, J. Interferon Cytokine Res. 15 (1995) 769-775.

[60] Niu P.D., Lefèvre F., Mege D., La Bonnardière C., Atypical porcine type I interferon. Biochemical and biological characterization of the recombinant protein expressed in insect cells, Eur. J. Biochem. 230 (1995) 200-206.

[61] Oezoernek M.H., Bielfeld P., Kruesel J.S., Cupisti S., Jeyendran R.S., Koldovsky U., Interferon- $\gamma$ production by the human preimplantation embryo, Am. J. Reprod. Immunol. 37 (1997) 435-437.

[62] Ozaki H., Ishii K., Houriuchi H., Arai H., Kawamoto T., Okawa K., Iwamatsu A., Kita T., Cutting edge: Combined treatment of TNF- $\alpha$ and IFN- $\gamma$ causes redistribution of junctional adhesion molecule in human endothelial cells, J. Immunol. 163 (1999) 553-557. 
[63] Paulesu L., Romagnoli R., Cintorino M., Ricci M.G., Garotta G., First trimester human trophoblast expresses both interferon- $\gamma$ and interferon- $\gamma$ receptor, J. Reprod. Immunol. 27 (1994) 37-48.

[64] Polgar K., Yacono P.W., Golan D.E., Hill Y.A., Immune interferon- $\gamma$ inhibits translational mobility of a plasma membrane protein in preimplantation stage mouse embryos: a T-helper 1 mechanism for immunologic reproductive failure, Am. J. Obstet. Gynecol. 174 (1996) 282-287.

[65] Rice A., Chard T., Cytokines in Implantation, Cytokine Growth Factor. Rev. 9 (1998) 287-296.

[66] Roberts R.M., Cross J.C., Leaman D.W., Interferons as hormones of pregnancy, Endocr. Rev. 13 (1992) 432-452.

[67] Short E.C., Geisert R.D., Helmer S.D., Zavy M.T., Fulton R.W., Expression of antiviral activity and induction of 2'-5' oligoadenylate synthetase by conceptus secretory proteins enriched in bovine trophoblast protein-1, Biol. Reprod. 44 (1991) 261-268.

[68] Stewart C.L., Kaspar P., Brunet L.J., Bhatt H., Gadi I., Koentgen F., Abbondanzo J., Blastocyst implantation depends on maternal expression of leukemia inhibitory factor, Nature 359 (1992) 76-79.

[69] Strickland S., Richards W.G., Invasion of the trophoblasts, Cell 71 (1992) 355-357.

[70] Stroband H.W.J., Van der Lende T., Embryonic and uterine development during early pregnancy in pigs, J. Reprod. Fertil. Suppl. 40 (1990) 261-277.

[71] Szente B.E., Johnson H.M., Binding of IFN- $\gamma$ and its C-terminal peptide to a cytoplasmic domain of its receptor that is essential for function,
Biochem. Biophys. Res. Commun. 201 (1994) 215-221.

[72] Tabibzadeh S.S., Satyaswaroop P.G., Differential expression of HLA-DR, HLA-DP and HLADQ antigenic determinants of the major histocompatiblity complex in human endometrium, Am. J. Reprod. Immunol. 18 (1989) 124-130.

[73] Tabibzadeh S.S., Satyaswaroop P.G., Rao P.N., Antiproliferative effect of interferon- $\gamma$ in human endometrial epithelial cells in vitro: potential local growth modulatory role in endometrium, J. Clin. Endocrinol. Metab. 67 (1988) 131-138.

[74] Tabibzadeh S.S., Sun X.Z., Kong Q.F., Kasnic G., Miller J., Satyaswaroop P.G., Induction of a polarised micro-environment by human $\mathrm{T}$ cells and interferon-gamma in three-dimensional spheroid cultures of human endometrial epithelial cells, Hum. Reprod. 8 (1993) 182-192.

[75] Thie M., Harrach-Ruprecht B., Sauer H., Fuchs P., Albers A., Denker H.W., Cell adhesion to the apical pole of epithelium: a function of cell polarity, Eur. J. Cell Biol. 66 (1995) 180-191.

[76] Vandenbroeck K., Dijkmans R., Van Aerschot A., Billiau A., Engineering by PCR-based exon amplification of the genomic porcine interferon-gamma DNA for expression in Escherichia coli, Biochem. Biophys. Res. Commun. 180 (1991) 1408-1415.

[77] Yamamoto S., Hase S., Yamauchi H., Tanimoto T., Ikenaka T., Studies on the sugar chains of interferon- $\gamma$ from human peripheral-blood lymphocytes, J. Biochem. 105 (1989) 1034-1039.

[78] Young H.A., Hardy K.J., Role of interferon- $\gamma$ in immune cell regulation, J. Leukoc. Biol. 58 (1995) 373-381.

To access this journal online: www.edpsciences.org 